\title{
Effects of experimental amitraz intoxication in cats
}

[Efeitos da intoxicação experimental por amitraz em gatos]

\author{
S.F. Andrade ${ }^{1}$, M. Sakate ${ }^{2}$, C.B. Laposy ${ }^{1}$, S.F. Valente $^{3}$, V.M. Bettanim ${ }^{4}$, \\ L.T. Rodrigues ${ }^{4}$, J. Marcicano ${ }^{4}$ \\ ${ }^{1}$ Universidade do Oeste Paulista - UNOESTE \\ Rodovia Raposo Tavares, Km 572 \\ 19067-175 - Presidente Prudente, SP \\ ${ }^{2}$ Faculdade de Medicina Veterinária e Zootecnia - UNESP - Botucatu, SP \\ ${ }^{3}$ Médico veterinário residente - UNOESTE - Presidente Prudente, SP \\ ${ }^{4}$ Aluno de graduação - UNOESTE - Presidente Prudente, SP
}

\begin{abstract}
This work studied the effects of experimental amitraz intoxication in cats. Sixteen cats were randomly divided equally into two groups: amitraz group - animals received $1.5 \%$ amitraz at $1 \mathrm{mg} / \mathrm{kg} \mathrm{IV}$; and the control group - animals without amitraz. Physiological parameters from blood, cardiorespiratory system, and sedation indicators were quantified over time up to 360 minutes. Blood profile, urea, creatinine, alananine aminotransferase and aspartate aminotransferase were not affected by amitraz. Sedation, loss of reflexes, hypothermia, bradycardia, bradyarrhythmia, hypotension, bradypnea, mydriasis, besides transitory hyperglycemia, hypoinsulinemia and decrease of cortisol levels were observed in cats experimentally exposed to amitraz. The $\alpha_{2}$-adrenergic effects induced by amitraz intoxication in cats are very similar to the same effects reported in others species, contributing with more information about this type of intoxication to veterinary toxicology.
\end{abstract}

Keywords: cat, amitraz, experimental intoxication

\section{RESUMO}

Este trabalho estudou os efeitos da intoxicação experimental por amitraz em 16 gatos, distribuídos, aleatoriamente, em dois grupos: grupo amitraz - animais receberam amitraz a 1,5\% na dose de 1,0 $\mathrm{mg} / \mathrm{kg} \mathrm{IV}$; e grupo controle - animais sem amitraz. Parâmetros fisiológicos sangüíneos, do sistema cardiorespiratório e de sedação foram aferidos até 360min. Perfil sangüineo, uréia, creatinina, alanina aminotransferase e aspartato aminotransferase não foram afetados pelo amitraz. Sedação, perda de reflexos, hipotermia, bradicardia, bradiarritmias, hipotensão, bradipnéia, midríase, além de transitória hiperglicemia, hipoinsulinemia e diminuição dos níveis de cortisol, foram observados nos gatos experimentalmente expostos ao amitraz. Os efeitos $\alpha_{2}$-adrenérgicos induzidos pela intoxicação por amitraz em gatos são muito similares aos mesmos efeitos relatados em outras espécies, contribuindo com mais informações dessa intoxicação para a toxicologia veterinária.

Palavras-chave: gato, amitraz, intoxicação experimental

\section{INTRODUCTION}

Amitraz is an insecticide of the formamidine group, initially synthesized in England in 1969, that is used as an acaricide and tickicide in veterinary medicine (Andrade and Sakate, 2004).
The mechanism of action of amitraz in arthropods occurs by the activation of octopaminergic receptors. In mammals, the main mechanism of action consists of activation of $\alpha_{2}$ adrenoceptors similar to the mechanism of action of xylazine and clonidine, agonist $\alpha_{2}$ -

Recebido em 18 de abril de 2007 
adrenergics, and in the inhibition of the enzyme monoaminoxidase (MAO) (Hsu, 1996).

Clinical signs occur due the $\alpha_{2}$-adrenergic effects induced by amitraz and include: sedation, loss of reflexes, lethargy and incoordination, bradycardia, bradyarrhythmia, hypotension, hypothermia, polyuria, transitory hyperglycemia, emesis, mydriasis and decrease of intestinal motility (Hsu, 1996; Andrade et al., 2004).

Amitraz is approved in Brazil by the Ministry of Agriculture for use in bovines, swine, sheep and dogs (Andrade and Sakate, 2004). Although its use is not recommended for cats by the manufacturer, it is an effective treatment of feline scabies and demodicosis (Cowan and Campbell, 1988; Scott et al., 1996) and is a very popular product, cheap and readily available, which could be an excellent alternative for acaricide treatment in this species (Andrade et al., 2004). However, few reports of amitraz intoxication are related to cats (Gunaratnam et al., 1983; Soli and Braseth, 1992; Andrade et al., 2004). Thus, the objectives of the present study were to investigate experimental amitraz intoxication and to analyze the $\alpha_{2}$-adrenergic effects induced by this acaricide in cats.

\section{MATERIAL AND METHODS}

The experiment was approved by the Ethical Committee (Protocol no. 47/2001). Sixteen mixed-breed adult cats, weighing $3.0 \pm 0.5 \mathrm{~kg}$, obtained from the cat pound were used. The cats were sorted by health condition and only those with physical (Lorens, 1996), hematological and biochemical (Willard et al., 1999) normal values were used. The day before running the experiment, the cats were socially isolated and held in individual stainless steel cages under 12:12 artificial light-dark cycle, room temperature at about $25^{\circ} \mathrm{C}$, and fed ad libitum.

The cats were randomly divided into two groups of eight animals each (four males and four females): a) amitraz group = cats were administered $1 \mathrm{mg}$ amitraz/kg IV as a $1.5 \%$ concentration (by dilution of $0.6 \mathrm{ml}$ of amitraz ${ }^{1}$,

${ }^{1}$ Mitrax $^{\circledR}$ - $(1000 \mathrm{ml} / 12.5 \mathrm{~g}$ amitraz $)$ Agribands Purina Paulínia, Brazil.
$75 \mathrm{mg}$, in $4.4 \mathrm{ml}$ of bi-distilled water ${ }^{2}$ ); and b) control group $=$ cats without any drug. This dose and dilution of amitraz were adapted from the amitraz intoxication model by iv route for dogs described in Andrade and Sakate (2003) and for cats in Andrade et al. (2006).

The following physical parameters were measured at 24 hours before and $0,30,60,120$, 180, 240 and $360 \mathrm{~min}$, and 24 hours after intoxication with amitraz: rectal temperature (T), respiratory rate (RR), heart rate (HR), systolic arterial pressure (SAP), electrocardiogram (ECG), pupil diameter (PD), degree of sedation (DS) and mean interval for sedation return (MISR).

The following scores were established for PD: normal (1), mydriasis (2), and myosis (3), and was evaluated by direct punctiform light toward the pupil. To measure DS the following scores were used: absent (0), mild (1), moderate (2), and high (3). Before intoxication all animals presented a score of 0 . MISR was the time necessary for the animal to recover protective pupillary, palpebral and interdigital reflexes after amitraz administration. SAP was measured by an indirect and non-invasive method, with Doppler Ultrasonic equipment ${ }^{3}$. ECG was obtained for cats in the right lateral recumbence, recorded by an automated electrocardiograph ${ }^{4}$. For each heart activity parameter, the mean value of 5 consecutive heartbeats was recorded on lead II. To evaluate cardiac rhythm, the following scores were used: a) sinusal; b) sinusal arrhythmia; c) sinusal bradycardia; d) $1^{\text {st }}$ degree A-V block; and e) sinus arrest (Goodwin, 2002).

For laboratory determinations, 24 hours before and after intoxication with amitraz, $3.5 \mathrm{ml}$ of blood samples were collected by jugular puncture with vacutainer $23 \mathrm{G}$ scalp $^{5}$ and a $5 \mathrm{ml}$ BD vacutainer tube $^{5}$ without additive, $0.5 \mathrm{ml}$ were transferred to a $1.0 \mathrm{ml}$ Eppendorf tube ${ }^{5}$ containing $20 \mu \mathrm{l}$ with EDTA (ethylenediaminetetraacetic acid) as anticoagulant for red blood cell (RBC) and white (WBC) blood cell counts. The $3.0 \mathrm{ml}$ of remaining blood were centrifuged for serum to obtain biochemical parameters of urea, creatinine, alanine aminotransferase (ALT), and aspartate

\footnotetext{
${ }^{2}$ Aster - Sorocaba, Brazil

${ }^{3}$ Parks Medical (841-A) - Aloha, USA

${ }^{4}$ Cardiotest EK 51 - USA.

${ }^{5} \mathrm{BD}$ - Becton Dickison - USA.
} 
aminotransferase (AST). The total $\mathrm{WBC}$ and $\mathrm{RBC}$ counts were determined using a hemocytometer. The WBC count used liquid of Turk as the diluent and differential counting of WBC used Diff-Quick. Manual counting of RBCs was accomplished using, as diluent, Hayen liquid. For hemoglobin concentration the cianometemoglobin method, and for hematocrit the microhematocrit method. The following biochemical proofs was determined by colorimetric methods: urea (urease) ${ }^{6}$, creatinine (fluid of the picric acid method) ${ }^{6}$, alanine aminotransferase (ALT) (Reitman-Frankel unit) ${ }^{6}$ and aspartate aminotransferase (AST) (ReitmanFrankel unit ${ }^{6}$ ).

At time intervals of $0,60,180$ and $360 \mathrm{~min}$ after amitraz intoxication for plasmatic glucose analysis and serum insulin and cortisol analysis, $4 \mathrm{ml}$ of blood samples were collected by jugular puncture with $23 \mathrm{G} 3 / 4$ vacutainer brand safety-lok blood collection sets ${ }^{5}$ and a $5 \mathrm{ml}$ BD vacutainer no additive tube ${ }^{5}$, being transferred $0.5 \mathrm{ml}$ for a $1.0 \mathrm{ml}$ Eppendorf tube ${ }^{5}$ containing $20 \mu \mathrm{l}$ with sodium fluoride for glucose dosage by colorimetric method (god-trinder oxidase) with spectrophotometric ${ }^{7}$ analysis. The remaining $3.5 \mathrm{ml}$ of blood in the tube without anticoagulant were centrifuged and $1.0 \mathrm{ml}$ of serum sample was transferred to another tube and stored frozen at $-40^{\circ} \mathrm{C}$ and were then submitted to the laboratory ${ }^{8}$ for insulin and cortisol analysis using a commercial radioimmunoassay ${ }^{9}$ (RIA) kit previously validated for cats by Nelson et al. (1990).

For each variable, a profile analysis (Morrison, 1990) was used to compare group and time effects. For non-parametric data, Friedmam (time effect evaluation) and Kruskal-Wallis (group effect evaluation) were used (Siegel, 1975). A significance level of $\mathrm{P}<0.05$ was adopted.

\section{RESULTS AND DISCUSSION}

The effects of amitraz on rectal temperature, respiration and heart activities are shown in Fig. 1. Amitraz reduced temperature after $60 \mathrm{~min}$ compared to the control group $(\mathrm{P}<0.05)$. This hypothermia is predictible, since temperature decreases with the use of $\alpha 2$ - adrenergic agonist

\footnotetext{
${ }^{6}$ LABTEST - Lagoa Santa, Brazil.

${ }^{7}$ CELM 225D - São Paulo, Brazil.

${ }^{8}$ Laboratório de Radioimunoensaio - CRIESP - São Paulo, Brazil.

${ }^{9}$ Diagnostic Products Inc. - Los Angeles, USA.
}

affect the thermoregulation center in the hypothalamus (Hsu, 1996).

Mean respiratory and heart rates were slightly increased in the beginning of the experiment in both groups, reaching normal values from the $60^{\text {th }} \mathrm{min}$ of the experiment. In the group control, changes in respiratory and heart rates may be increased by the influence of the sympathetic nervous system during stress (Noble, 2002). Amitraz decreased the respiratory rate at times 180,240 and $360 \mathrm{~min}$ relative to the respective controls (Fig. 1). Respiratory depression induced by amitraz is possibly due to the central $\alpha_{2}$-adrenergic action of this acaricide (Cockburn et al., 1993).

Amitraz administration induced a heart-rate decrease from $30 \mathrm{~min}$ to $360 \mathrm{~min}$ (Fig. 2), with the greatest reduction at $60 \mathrm{~min}$, corresponding to a decrease of $37.7 \%$ in relation to time zero. SAP was decreased in control cats from times 180 to $240 \mathrm{~min}$. A more pronounced decrease was induced by amitraz, with SAP decreasing from 30min until the end of the experiment (Fig. 1). Among the groups, significant differences were detected $(\mathrm{P}<0.05)$ from 30 to $360 \mathrm{~min}$ after amitraz administration. Bradycardia and hypotension after administration of amitraz may be due to activation of central presynaptic $\alpha_{2}$ receptors, decreasing release of dopamine and noradrenaline and reducing sympathetic tonus (Hoffman and Lefkowitz, 1996).

The ECG average values were normal at all times in the two experimental groups. Although the values were within normality, four cats individually presented abnormal values after amitraz administration: one cat prolonged PR interval $(0.10 \mathrm{~s})$ [cat No. 2 at 20 and $180 \mathrm{~min}$ ], and three cats presented QT larger than $0.18 \mathrm{~s}$ [cat No. 3 at 30 and $60 \mathrm{~min}$; cat No. 5 at 120 and $180 \mathrm{~min}$; and cat No. 8 at 120 and $240 \mathrm{~min}$ ].

All control cats presented normal sinusal rhythm. Amitraz, however, induced several arrhythmias, such as sinusal bradycardia, sinusal arrhythmia and first A-V block ( $\left.1^{\text {st }} \mathrm{AVB}\right)$, shown in Fig. 2. Cat No. 2 presented sinusal bradycardia at times 30, 60 (Fig. 2) and $240 \mathrm{~min}$, first $\mathrm{A}-\mathrm{V}$ block at times 120 and $180 \mathrm{~min}$ (Fig. 2), and sinusal arrhythmia at $360 \mathrm{~min}$. Cat No. 5 had sinusal bradycardia at $180 \mathrm{~min}$ and $240 \mathrm{~min}$. Cat No. 7 revealed bradycardia at $30 \mathrm{~min}$ and sinusal arrhythmia at times $120 \mathrm{~min}$ and $180 \mathrm{~min}$. Cat No. 8 showed sinusal arrhythmia at time 240min. 

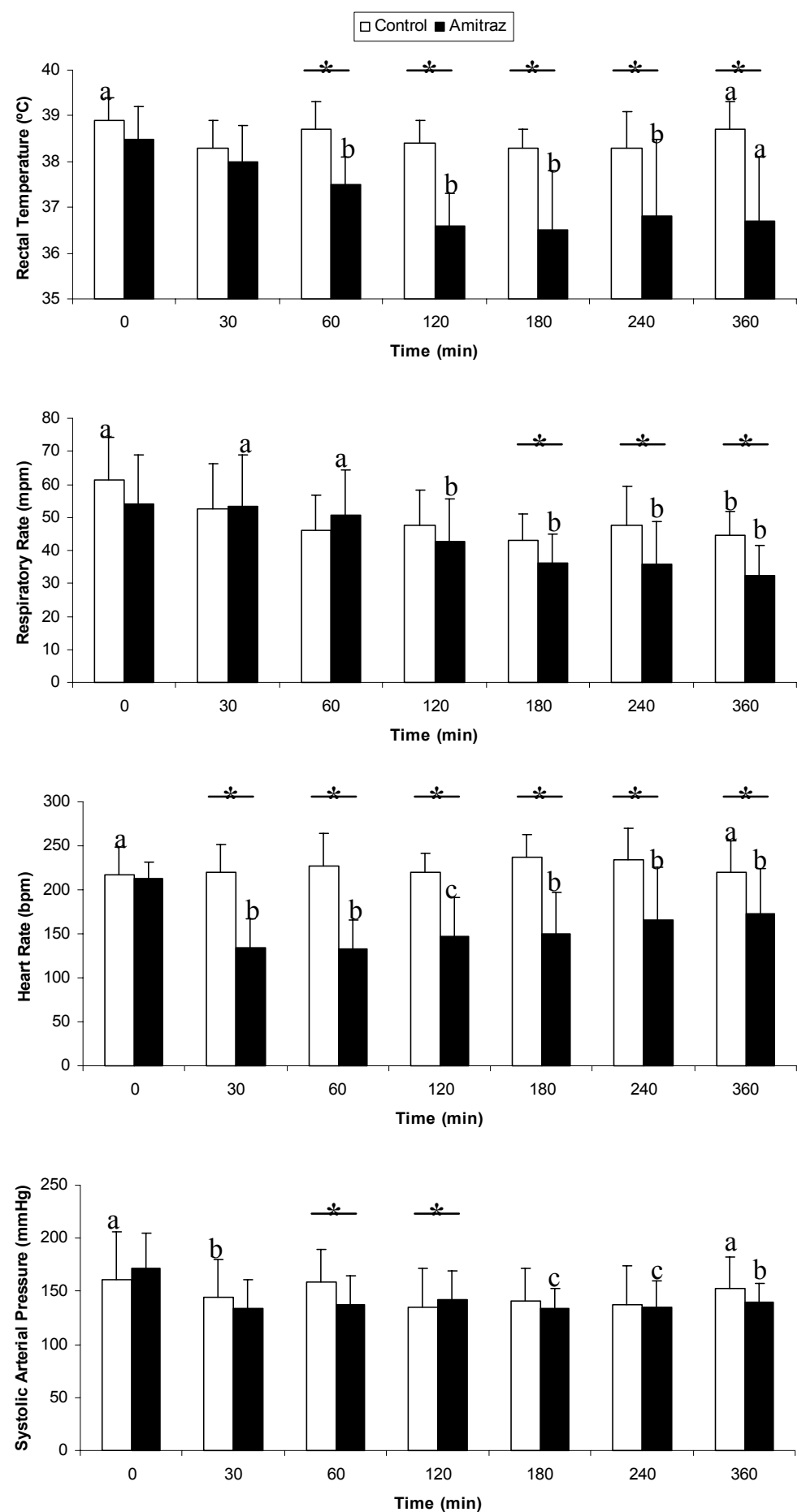

Figure 1. Effects of experimental amitraz intoxication on rectal temperature and cardiorespiratory parameters in cats. Values as mean $( \pm$ sd $)$ from eight cats each condition. Different lower-case letters above the mean indicate significant difference (Friedman, $\mathrm{P}<0.05$ ). Asterisk indicates statistical difference between groups (Kruskal-Wallis, $\mathrm{P}<0.05$ ). 
Sinusal rythm of cat no. 1 in T360 (control

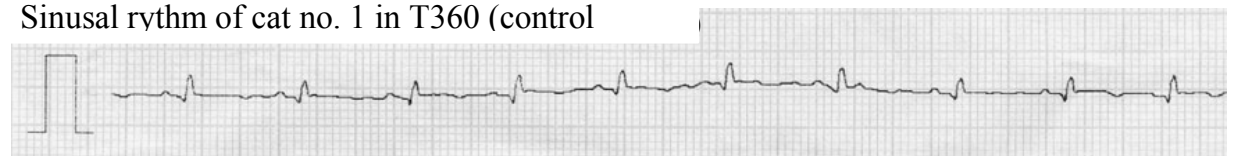

Sinusal bradycardia of cat no. 2 in T60 (amitraz

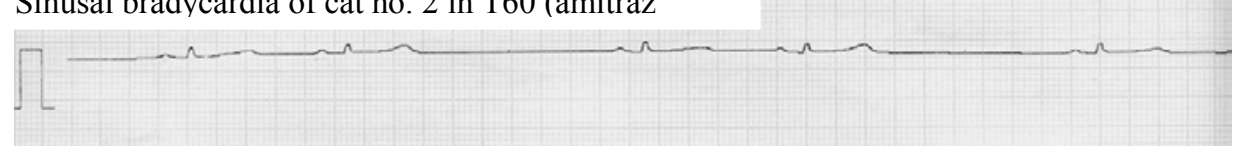

First AVB of cat no. 2 in T180 (amitraz

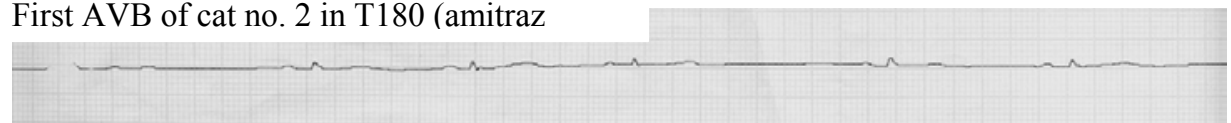

Figure 2. Examples of cardiac patterns in cats. ECGs from lead II (paper speed $=50 \mathrm{~mm} / \mathrm{sec} ; 1 \mathrm{~cm}=1 \mathrm{mv}$; $35 \mathrm{~Hz} ; 60 \mathrm{~Hz})$.

This study describes the first report of sinusal bradycardia and $1^{\text {st }}$ degree A-V block induced by amitraz in cats. Prolongation of PR interval indicates $1^{\text {st }}$ degree $\mathrm{A}-\mathrm{V}$ block $\left(1^{\text {st }} \mathrm{AVB}\right)$ (Goodwin, 2002). The variation of the PR interval may occur in the case of vagal tonus alteration or secondarily to ectopic focus, causing dissociation of the atrial and ventricular activities (Zipes, 1992). The $\alpha_{2}$-adrenergics agonists reduce CNS sympathetic tonus, increase parasympathetic activity, and induce sinusal bradycardia or $1^{\text {st }}$ or $2^{\text {sd }}$ degree A-V block; yet, complete $3^{\text {rd }}$ degree A-V block with escape pulsations rarely occurs (Zipes, 1992; Goodwin, 2002).

Amitraz provoked mydriasis until 240min (Fig. 3 ). In the amitraz group, cats showed high sedation at $30 \mathrm{~min}$, a response significantly different compared to time zero $(\mathrm{P}>0.05)$ until 240min (Fig. 3). Amitraz caused dose-dependent mydriasis and sedation mediated by postsynaptic $\alpha_{2}$ adrenoceptors (Hsu and Kakuk, 1984). The MISR after amitraz administration was $175.0 \pm 70.7 \mathrm{~min}$.

Amitraz increased plasma glucose levels only from $60 \mathrm{~min}$, both to time zero and the $60-\mathrm{min}$ control (Fig. 4). This represented a 95.3\% increase compared to time zero. The amitrazincreased serum glucose reached a maximum at $60 \mathrm{~min}$ and then gradually decreased until 360min. In some cats, amitraz caused hyperglycemia (above $200 \mathrm{mg} / \mathrm{dl}$ ) at $60 \mathrm{~min}$ : cats No. $3(225.5 \mathrm{mg} / \mathrm{dl})$, No. $5(222.8 \mathrm{mg} / \mathrm{dl})$ and No. $8(209.4 \mathrm{mg} / \mathrm{dl})$. The transitory hyperglycemia observed in cats intoxicated by amitraz was very similar to that reported in dogs by Andrade et al. (2005). The hyperglycemia occurs by the action of amitraz and its active metabolite, BTS 27271, by $\alpha_{2}$-adrenergic-receptor-mediated inhibition of insulin secretion, possibly by adenylciclase inhibition mediated by G PTX-sensitive proteins (Chen and Hsu, 1994). The $\alpha_{2}$-adrenergic receptor subtype involved in this action is $\alpha_{2 \mathrm{D}}$, which is located within the pancreatic islets (Abu-Basha et al., 1999).

There are interests in human medicine for the possible role of $\alpha_{2}$-adrenergic receptors to decrease the activity of pancreatic cells in patients with diabetes type 2 (Ortiz-Alonso et al., 1991). It is quite evident that these patients are more sensitive to amitraz intoxication than normal individuals, thus requiring more studies on this topic (Abu-Basha et al., 1999).

Insulin significantly decreased at $180 \mathrm{~min}$ and $360 \mathrm{~min}$ in the control cats, but within the basal range for cats. Amitraz decreased insulin with respect to control cats at $60 \mathrm{~min}$, though subsequently insulin increased at $180 \mathrm{~min}$ and 360min. 
Control cats showed serum cortisol levels slightly increased over all times quantified and no time effect was observed. Amitraz decreased plasma cortisol only at $60 \mathrm{~min}$. Cats administered amitraz showed that cortisol serum level increased at time zero. Plasma cortisol, insulin and glucose concentrations are altered in stressed animals (Noble, 2002). In the present study, serum cortisol levels in the control cats were slightly increased at some times $(0,180$ and $360 \mathrm{~min}$ ), and cats from the amitraz group slightly increased plasma cortisol at time zero.
However, such slight increase in cortisol may result from handling stress, as has been described in the literature (Oppermann and Baken, 1997). Amitraz-induced cortisol decrease may be a consequence of CNS depression caused by $\alpha_{2-}$ adrenergic central receptor stimulation, resulting mainly in decreased sympathetic CNS efflux, catecholamine, and other substances related to stress (Noble, 2002; Miller and O'Callaghan, 2002).
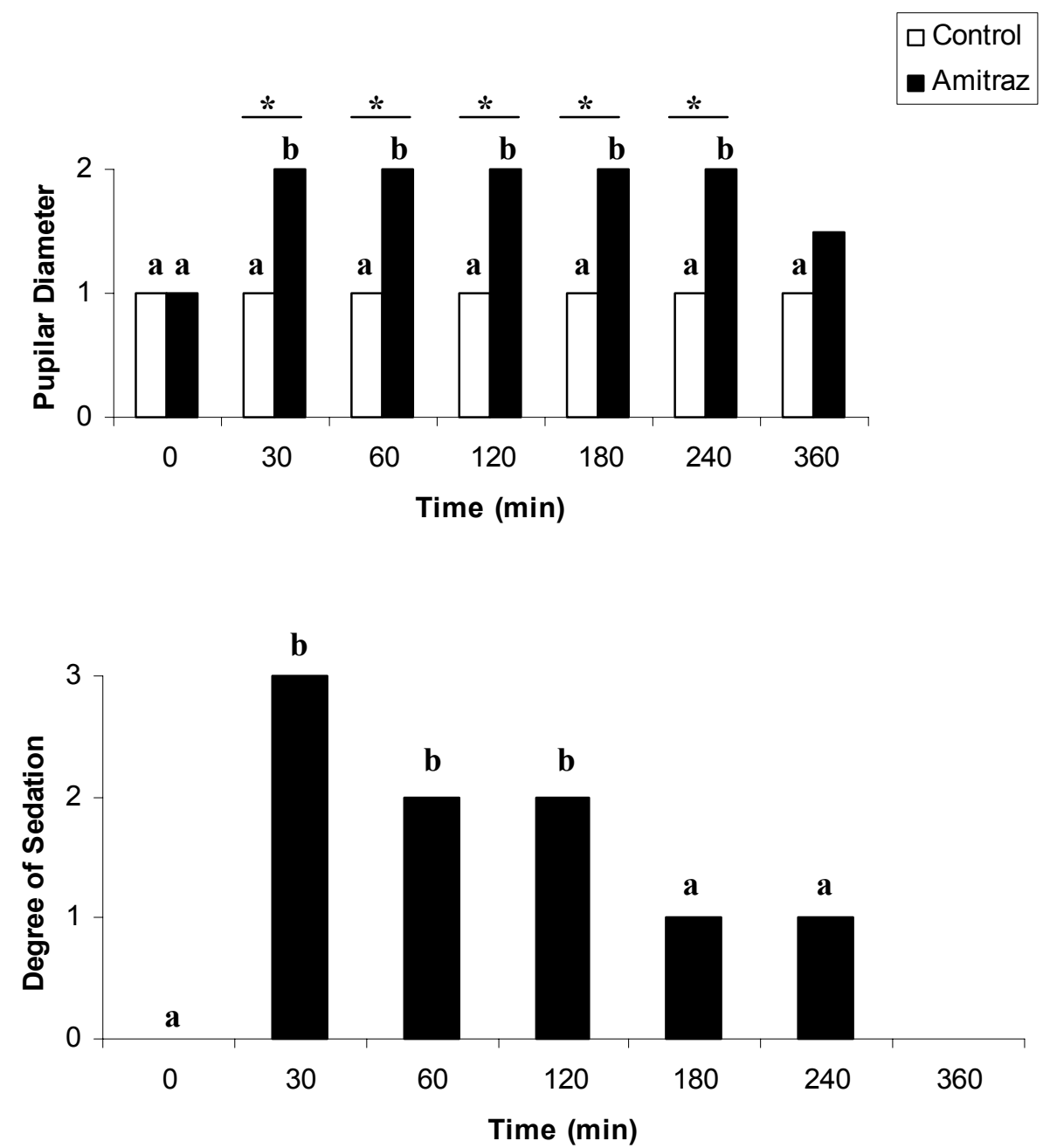

Figure 3. Effects of experimental amitraz intoxication on medians of pupilar diameter and degree of sedation in cats. Pupilar diameter was scored as normal (1), mydriasis (2) or myosis (3). Degrees of sedation are shown only for the Amitraz group and responses were scored as absent (0), mild (1), moderate (2) or high (3). Values from eight cats each condition. Different lower-case letters above medians indicate significant difference among moments and within a group (Friedman, $\mathrm{P}<0.05$ ). Asterisk indicates statistical difference between groups (Kruskal-Wallis, $\mathrm{P}<0.05$ ). 

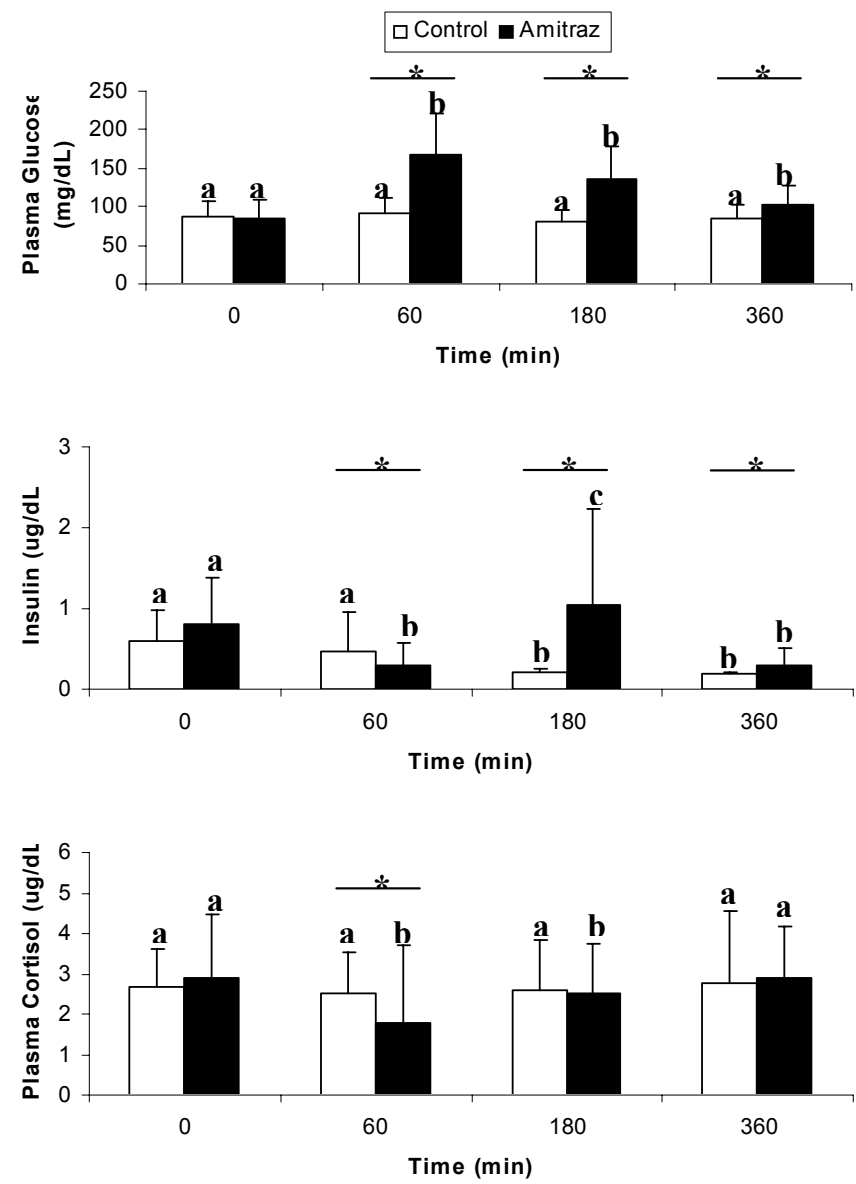

Figure 4. Effects of experimental amitraz intoxication on metabolism (metabolite and hormones) in cats. Mean $( \pm$ sd) values from eight cats in each condition. Values as mean $( \pm$ sd) from eight cats each condition. Different lower-case letters above the mean indicate significant difference (Profile analysis, $\mathrm{P}<0.05$ ). Asterisk indicates statistical difference between groups (Profile analysis, $\mathrm{P}<0.05$ ).

RBC, WBC, urea, creatinine, ALT and AST values were not affected by amitraz administration $\quad(\mathrm{P}>0.05)$. These observations have also been described by other authors in cats (Gunaratnan et al., 1983), in humans (Atabek et al., 2002), in horses under prolonged use of amitraz by intravenous route (Queiroz-Neto et al., 2002) and in mice (Filazi et al., 2003). Other clinical signs which occurred only in cats intoxicated with amitraz were vomit $(62.5 \%)$, sialorrhea $(50.0 \%)$, diuresis increase $(25.0 \%)$, vocalization $(25.0 \%)$ and ataxia $(62.5 \%)$.

An interesting aspect was the increase in appetite (50.0\%) after the end of the experiment in cats intoxicated by amitraz, a formamidine pesticide. Formamidines are a new class of appetite stimulants in mice (Pfister et al., 1978) and furthermore, the $\alpha_{2}$-adrenergic agonist in low dosages can stimulate appetite (Hall and Taylor, 1994). The present study is the first demonstration of such an action in cats.

The clinical signs observed in cats intoxicated by amitraz were: sedation, loss of reflexes, hypothermia, bradycardia, bradyarrhythmia, hypotension, bradypnea and mydriasis. Some cats also presented vomiting, diuresis, sialorrhea, vocalization and increased appetite. The bradyarrhythmias observed were sinusal bradycardia and $1^{\text {st }}$ degree A-V block. Metabolic and hormonal alterations were transitory hyperglycemia and hipoinsulinemia and transitory decrease of plasma levels of cortisol. Amitraz intoxication in cats did not change RBC, WBC, urea, creatinine, ALT or AST concentrations. 
These results demonstrate that amitraz intoxication in cats is very similar to the same reported of this intoxication in others species.

\section{ACKNOWLEDGEMENTS}

The authors thank the Post-graduation program of UNOESTE for financial support, the Postgraduation program of FMVZ-UNESP-Botucatu, for orientation, and Dr. Luzia Trinca from Instituto de Biociências - UNESP - Botucatu, for statistical analysis.

\section{REFERENCES}

ABU-BASHA, E.A.; YIBCHOK-ANUN, S.; $\mathrm{HSU}, \mathrm{H}$. et al. Effects of the pesticide amitraz and its metabolite BTS 27271 on insulin and glucagon secretion from the perfused rat pancreas: involvement of $\alpha_{2 \mathrm{D}}$-adrenergic receptors. Metabolism, v.48, p.1461-1469, 1999.

ANDRADE S.F.; SAKATE, M. The comparative efficacy of yohimbine and atipamezole to treat amitraz intoxication in dogs. Vet. Hum. Toxicol., v.45, p.124-127, 2003.

ANDRADE S.F.; SAKATE, M. Intoxicação por amitraz. Vet. Not., v.10, p.101-109, 2004.

ANDRADE S.F; SANCHEZ, O.; TOSTES, R.A. Relato de 5 casos de intoxicação por amitraz em cães e gatos. Clín. Vet., v.53, p.38-42, 2004.

ANDRADE S.F.; SAKATE, M.; CROCCI, A.J. Effects of yohimbine and atipamezole on plasmatic glucose concentration and blood gas analysis in dogs intoxicated with Triatox ${ }^{\circledR}$. ARS Vet., v.21, p.121-128, 2005.

ANDRADE S.F.; SAKATE, M.; LAPOSY, C.B. et al. Yohimbine and atipamezole on the treatment of experimentally induced amitraz intoxication in cats. Int. J. App. Vet. Med., v.4, p.200-208, 2006.

ATABEK, M.E.; AYDIN, K.; ERKUL, I. Different clinical features of amitraz poisoning in children. Hum. Exper. Toxicol., v.21, p.13-16, 2002.

CHEN, T.H.; HSU, W.H. Inhibition of insulin release by a formamidine pesticide amitraz and its metabolites in a rat beta-cell line: an action mediated by alpha-2 adrenoceptors, a GTPbinding protein and decrease in cyclic AMP. $J$.
Pharmacol. Exp. Therap., v.273, p.1240-1245, 1994.

COCKBURN, A.; HARVEY, P.W.; NEEDHAM, D. et al. Double blind human single dose tolerance study of amitraz with evaluation of autonomic, sensory and psychomotor function. Hum. Exper. Toxicol., v.12, p.571-573, 1993.

COWAN, L.A.; CAMPBELL, K. Generalized demodicosis in a cat responsive to amitraz. $J$. Am. Vet. Med. Assoc., v.192, p.1442-1444, 1988.

FILAZI, A.; SIRELI, M.; KALKAN, F. The influence of amitraz on biochemical parameters in mice. Hum. Exp. Toxicol., v.22, p.99-101, 2003.

GOODWIN, J.K. Eletrocardiografia. In: TILLEY, L.P.; GOODWIN, J.K. Manual de cardiologia para cães e gatos. São Paulo: Roca, 2002. p.39-65.

GUNARATNAN, P.; WILKINSON, G.T.; SEAWRIGHT, A.A. A study of amitraz toxicity in cats. Austr. Vet. J., v.60, p.278-279, 1983.

HALL, L.W.; TAYLOR, P.M. Anaesthesia of the cat. London: Bailliére Tindall, 1994. 291p.

HOFFMAN, B.B; LEFKOWITZ, R.J. Catecholamines, sympathomimetic drugs, and adrenergic receptor antagonists. In: GOODMAN L.S.; GILMAN A.G. (Eds). The pharmacological basis of therapeutics. New York: MacMillan, 1996. p. 199-248.

HSU, W.H.; KAKUK, T.J. Effect of amitraz and chlordimeform on heart rate and pupil diameter in rats: Mediates by $\alpha_{2}$ - adrenoceptors. Toxicol. Appl. Pharmacol., v.73, p.411-415, 1984.

HSU, W.H. Antiparasitic Agents. In: AHRENS, F.A. (Ed). Farmacology. Baltimore: Willians \& Wilkins, 1996. p.243-260.

LORENS, M.D; CORNELIUS, L.M. Diagnóstico clínico em pequenos animais,2.ed., Rio de Janeiro: Interlivros, 1996. 530p.

MILLER, D.B.; O'CALLAGHAN, J.P. Neuroendocrine aspects of the response to stress. Metabolism, v.51, p.5-10, 2002.

MORRISON, D.F. Multivariate statistical methods. New York: McGraw-Hill, 1990. 495p.

NELSON, R.W.; HIMSEL, C.A.; FELDMAN, E.C. et al. Glucose tolerance and insuline 
response in normal-weigh and obese cats. Am. $J$. Vet. Res., v.51, p.1357-1362, 1990.

NOBLE, R.E. Diagnosis of stress. Metabolism, v.51, p.37-39, 2002.

OPPERMANN, R.; BAKKEN, M. Effects of handling and physical restraint on rectal temperature, cortisol, glucose and leukocyte counts in the Silver Fox (Vulpes vulpes). Acta Vet. Scand., v.38, p.29-39, 1997.

ORTIZ-ALONSO, F.J.; HERMAN, W.H.; GERTZ, B.J. Effect of an $\alpha_{2}$-adrenergic blocker (MK-912) on pancreatic islet function in noninsulin-dependent diabetes mellitus. Metabolism, v.40, p.1160-1167, 1991

PFISTER, W.R.; HOLLINGWORTH, R.M.; YIM, G.K. Increased feeding in rats treated with chlordimeform and related formamidines: a new class of appetite stimulants. Psychopharmacology, v.60, p.47-51, 1978.

QUEIROZ-NETO, A.; D'ANGELIS, F.H.F.; HARKINS, J.D. et al. Avaliação toxicológica da administração intravenosa crônica de amitraz em eqüinos. Arq. Bras. Med. Vet. Zootec., v.54, p.345-350, 2002.

SCOTT, D.W.; MILLER, W.H.; GRIFFIN, C.E. (Eds). Dermatologia de pequenos animais. Rio de Janeiro: Interlivros, 1996. 1130p.

SIEGEL, S. Estatística não paramétrica para as ciências do comportamento, New York : McGraw-Hill, 1975. 350p.

SOLI, N.E.; BRASETH, T.A. Ectodex poisoning in a cat reversed with Antisedan. NorskVeterinaertidsskrift, v.104, p.25-26, 1992.

WILLARD, M.D.; TVEDTEN, H.; TURNWALD, G.H. (Eds). Small animal clinical diagnosis by laboratory methods. Philadelphia: WB Saunders, 1999. 395p.

ZIPES, D.P. Specific arrhythmias: diagnosis and treatment. In: BRAUNWALD, E. (Ed). Heart disease: a textbook of cardiovascular medicine. Philadelphia: WB Saunders, 1992. p.667-725. 